\title{
NEW BIOGEOGRAPHIC DATA AND DNA BARCODES \\ FOR THE INDIAN SWELLSHARK, CEPHALOSCYLLIUM SILASI (TALWAR, 1974) (ELASMOBRANCHII: CARCHARHINIFORMES: SCYLIORHINIDAE), FROM ANDAMAN WATERS
}

\author{
Ravi Ranjan KUMAR ${ }^{1}$, S. VENU ${ }^{1}$, K.K. BINEESH ${ }^{2}$, and V.S. BASHEER ${ }^{2}$ \\ ${ }^{1}$ Department of Ocean Studies and Marine Biology, Pondicherry University, Port Blair, Andaman Islands, India \\ ${ }^{2}$ National Bureau of Fish Genetic Resources, PMFGR Centre, CMFRI Campus, Ernakulam North, \\ Kerala, India
}

\begin{abstract}
Kumar R.R., Venu S., Bineesh K.K., Basheer V.S. 2016. New biogeographic data and DNA barcodes for the Indian swellshark, Cephaloscyllium silasi (Talwar, 1974) (Elasmobranchii: Carcharhiniformes: Scyliorhinidae), from Andaman waters. Acta Ichthyol. Piscat. 46 (2): 131-135.
\end{abstract}

\begin{abstract}
Indian swellshark, Cephaloscyllium silasi (Talwar, 1974), is reported for the first time in Andaman waters, India which is a considerable extension of its known distribution range with more than $1000 \mathrm{~km}$ toward eastern Indian EEZ. This is the first confirmed geographic distributional record of poorly known deep-water Indian swellshark, C. silasi, in the Andaman waters and first outside its type locality. A detailed morphological description of $C$. silasi collected from Andaman waters and comparison with other known materials along with the molecular barcodes are provided.
\end{abstract}

Keywords: new record, morphology, molecular systematics, Indian EEZ

The fish fauna of Indo-Pacific is one of the most diverse due to the zoogeographical importance of region (Randall 1998, Kimura et al. 2009, Hubert et al. 2012). Andaman Islands and surrounding waters in the Indian EEZ have a rich marine biodiversity that is largely unexplored. Rajan et al. (2012) reported 39 sharks from the waters around Andaman and Nicobar Islands of India.

Swellsharks of the genus Cephaloscyllium are very small to medium sized sharks, most of them having no commercial significance due to its small size and abundance. They are known as swellsharks or balloon sharks because of their characteristic ability to inflate/swell body by swallowing air or seawater to deter predation or when out of the water (Inoue and Nakaya 2006, Schaaf-Da Silva and Ebert 2008). Genus Cephaloscyllium Gill, 1862 currently contains 17 valid species (Weigmann 2016) of which the Indian swellshark, Cephaloscyllium silasi (Talwar, 1974), originally described from southeastern Arabian Sea as "Scyliorhinus (Halaelurus) silasi" is the only valid species of genus in Indian EEZ (Akhilesh et al. 2014a).

The knowledge on the elasmobranch diversity in the Indian EEZ is rather scarce. In a recent checklist Akhilesh et al. (2014b) suggested that approximately 160 species are known from Indian waters with several species requiring confirmation of their taxonomic status. Bineesh et al.
(2016) revealed the species composition of sharks and rays in the Indian commercial fishery using DNA barcoding and 11 elasmobranch species were confirmed first records for Indian waters.

The present report of Cephaloscyllium silasi from the region is a new addition to shark fauna of Andaman waters. This paper present the first report of Cephaloscyllium silasi with molecular confirmation based on DNA barcoding of recently collected specimens from deep waters in Andaman waters which is a considerable extension from its known distribution range east coast of Indian EEZ.

Three specimens of Cephaloscyllium silasi were collected from the deep-sea shrimp trawler bycatch landings from Junglighat fish landing centre, Port Blair, Andamans, India. The deep-sea shrimp trawler operated off North Sentinel Island of Andaman and Nicobar Islands (Fig. 1) at a depth range of 150-300 m. Morphometric measurements were recorded following Compagno (2001). The specimens were identified following (Talwar 1974, Compagno et al. 2005, Akhilesh et al. 2014a). Tissue samples collected were preserved in $95 \%$ ethanol and DNA was extracted by standard protocols (Miller et al. 1988). Partial sequence information of mitochondrial gene, Cytochrome c oxidase subunit I (COI) was generated (Ward et al. 2005) by bidirectional

* Correspondence: Ravi Ranjan Kumar, Department of Ocean Studies and Marine Biology, Pondicherry University, Port Blair, Andaman Islands, 744 112, India, e-mail (RRK) raviranjan1750@gmail.com, (SV) s.venu1974@gmail.com, (KKB) kkbineesh@gmail.com, (BVS) vsbasheer@gmail.com. 

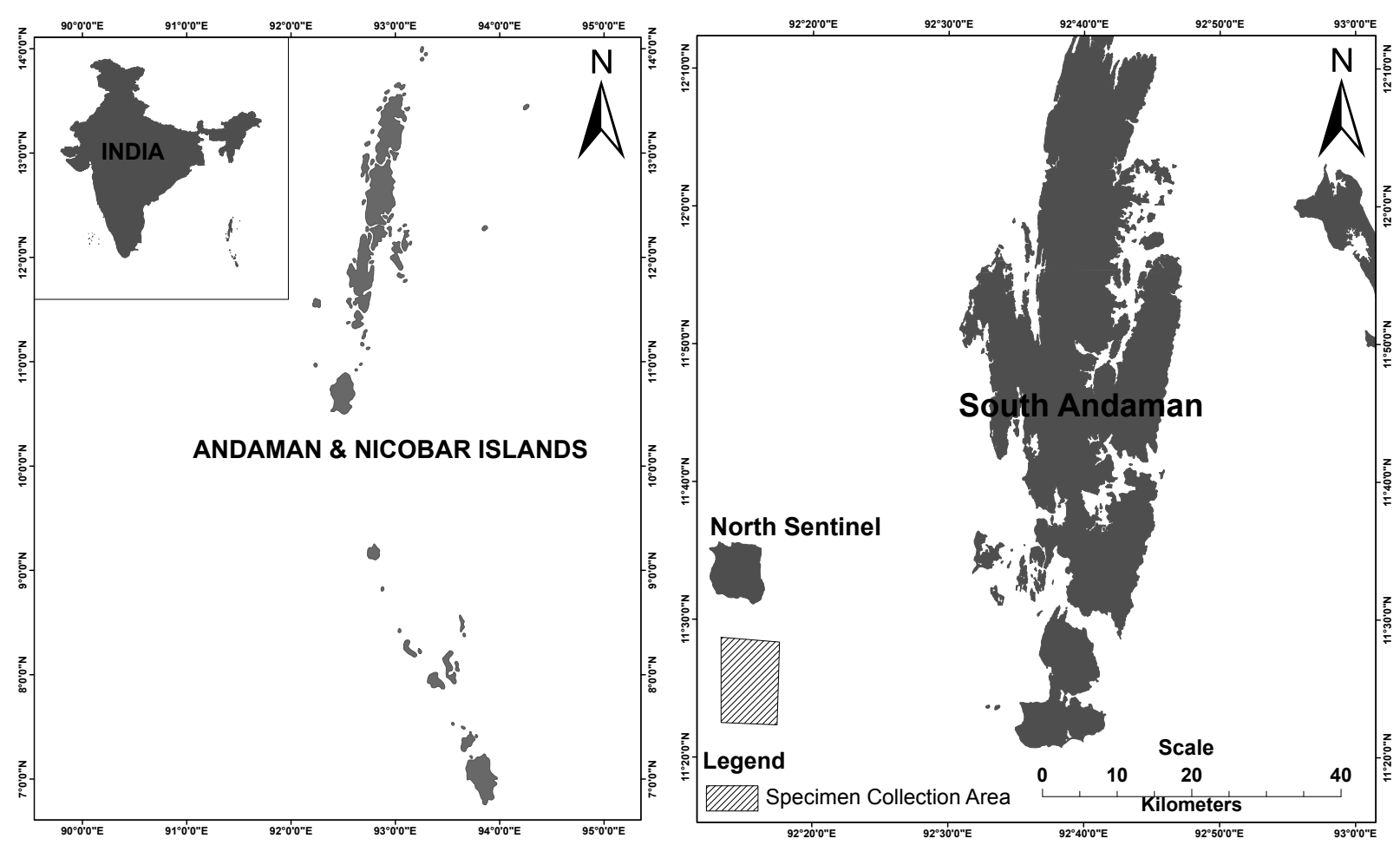

Fig. 1. Map showing collection location of Cephaloscyllium silasi from Andaman waters

sequencing using ABI 3730 sequencer. The edited sequences of Cephaloscyllium silasi were submitted to the NCBI database (KU841524 and KU841525). Additional sequences of Cephaloscyllium spp. were downloaded from the NCBI database for analysis, which are follows EU398669-EU398676, HM909795, DQ108322, and GU440268.

\section{Family SCYLIORHINIDAE}

Genus Cephaloscyllium Gill, 1862

Cephaloscyllium silasi (Talwar, 1974)

Description of material from Andaman waters. Stout body and expanded belly (Figs. 2-3). No labial furrows, anterior nasal flaps broadly triangular. Head depressed, flattened and broad, rounded in dorsal and ventrally, mouth large and arched. Proportional measurements in percentage of total length presented in Table 1.

Colour. Seven dark brown bands dorsally over body, two comparatively small bands near pectoral fins; remaining dorsal part of body pale brown. Ventral portion pale. Caudal tip end with small dark brown band.

Geographical distribution. Gulf of Aden (Manilo 1993) to Andaman waters. Many species from Andaman waters are recently been reported from southwest coast of India and vice versa suggesting a similar deep habitat in the region or a change in the current pattern.

DNA barcoding results. The partial sequence of mitochondria COI gene produced a mean value of 655 nucleotide base pairs. Pair-wise genetic distance values (K2P) based on COI sequences using MEGA 6.1. Neighbour Joining (NJ) trees of Kimura two parameter (K2P) distances were created to provide a graphic representation of the patterning of divergences (Fig. 4). A comparison of the DNA barcode of present Andaman specimens shows a 99.2\% match with Cephaloscyllium silasi from India (GenBank: KF899707-KF899711).

Remarks. A detailed redescription with morphological data was presented from Arabian Sea, off Kollam (Kerala) south-west coast of India at a depth range of 250-500 m Akhilesh et al. (2014 a). Morphometric measurements of presently collected Cephaloscyllium silasi has been compared with that of Akhilesh et al. (2014a) for the species confirmation and its comparison with earlier reports. Compagno et al. (2005) and Ebert et al. (2013) suggested a Cephaloscyllium similar to C. silasi occurs in Andaman waters, with the present morphometric comparisons and genetic results we suggest it is a considerable range extension of Cephaloscyllium silasi.

\section{ACKNOWLEDGEMENTS}

The authors are grateful to the Director, NBFGR, for the support and providing facilities to carry out the DNA barcoding study. Dr. Akhilesh K.V (CMFRI) is acknowledged for his comments on the earlier version of manuscript. The Pondicherry University is acknowledged for providing the facilities. Thanks are also due to Rajiv Gandhi National fellowship (RGNF) for Ravi Ranjan Kumar. We also thanks to Mr. Balakrishna, Department of Disaster Management for designing the map. Thanks to fishermen and merchants at Junglighat fish landing center, Andaman Islands for their kind support and cooperation. 
Table 1

Morphometric measurements (\% TL) of Cephaloscyllium silasi from Andaman waters compared with known materials

\begin{tabular}{|c|c|c|c|c|c|c|c|c|c|c|c|c|c|}
\hline Meast & 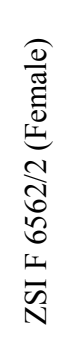 & 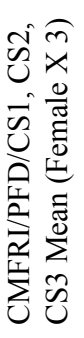 & 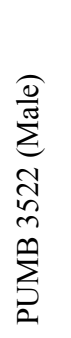 & 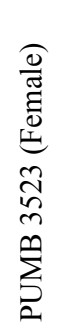 & 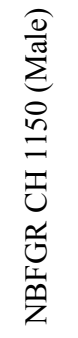 & हे & Measurement & 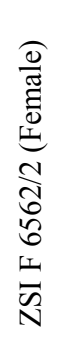 & 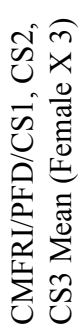 & 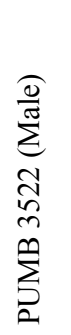 & 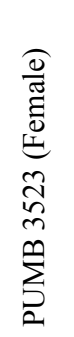 & 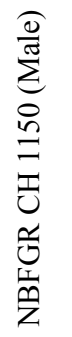 & हे \\
\hline Total length (1 & 318 & 432.3 & 364 & 253 & 330 & - & \multirow{2}{*}{$\begin{array}{l}\text { Pectoral fin-posterior } \\
\text { margin length }\end{array}$} & \multirow[t]{2}{*}{11.2} & \multirow[t]{2}{*}{11.9} & \multirow[t]{2}{*}{9.6} & \multirow[t]{2}{*}{9.1} & \multirow[t]{2}{*}{12.7} & \multirow[t]{2}{*}{1.5} \\
\hline Pre-caudal length & 76.7 & 79.9 & 78.3 & 77.5 & 77.0 & 1.3 & & & & & & & \\
\hline Pre-second dorsal length & 63.8 & 68.5 & 66.2 & 64.8 & 65.2 & 1.8 & Pelvic fin length & 5 & 11.9 & 11.8 & 11.2 & 11.8 & 3.0 \\
\hline Pre-first dorsal length & 49.1 & 53.8 & 51.1 & 50.2 & 51.8 & 1.8 & \multirow{2}{*}{$\begin{array}{l}\text { Pelvic fin-anterior margin } \\
\text { length }\end{array}$} & \multirow[t]{2}{*}{6.6} & \multirow[t]{2}{*}{6.2} & \multirow[t]{2}{*}{6.0} & \multirow[t]{2}{*}{5.5} & \multirow[t]{2}{*}{7.0} & \multirow[t]{2}{*}{0.5} \\
\hline Head length (direct) & 24 & 27.0 & 25.0 & 22.5 & 24.5 & 1.6 & & & & & & & \\
\hline Pre-branchial length & 24 & 19.9 & 17.5 & 17.7 & 19.5 & 2.6 & \multirow{4}{*}{$\begin{array}{l}\text { Pelvic fin base length } \\
\text { Pelvic fin height } \\
\text { Pelvic fin-inner margin } \\
\text { length }\end{array}$} & 5 & 8.9 & 8.0 & 7.5 & 9.1 & 1.6 \\
\hline Pre-spiracular length & 11.9 & 11.0 & 10.2 & 9.1 & 9.4 & 1.2 & & 5.6 & 5.4 & 6.0 & 3.6 & 4.2 & 1.0 \\
\hline Pre-orbital length (direct) & 7 & 6.7 & 6.0 & 5.5 & 4.9 & 0.9 & & - & 3.2 & 3.3 & 2.4 & 3.8 & 1.5 \\
\hline Pre-oral length & 4.1 & 3.9 & 4.9 & 4.7 & 4.8 & 0.5 & & & & & & & \\
\hline Pre-narial length & 2.5 & 4.0 & 2.5 & 2.4 & 2.1 & 0.7 & $\begin{array}{l}\text { Peivic in } \\
\text { length }\end{array}$ & 1.4 & 1.2 & 8.5 & 5.9 & 9.1 & \\
\hline Pre-pectoral length & 22 & 26.0 & 20.4 & 20.9 & 21.3 & 2.2 & First dorsal fin length & 9.3 & 9.5 & 8.5 & 9.1 & 9.1 & 0.4 \\
\hline Pre-pelvic length & 45.7 & 50.2 & 46.4 & 45.5 & 44.2 & 2.3 & & 10 & 10.3 & 9.3 & 9.5 & 10.0 & 0.4 \\
\hline Snout-vent distance & 48.6 & 53.2 & 51.1 & 48.5 & 47.9 & 2.2 & & & & & & & \\
\hline Pre-anal length & 60.1 & 66.4 & 63.2 & 60.1 & 61.8 & 2.6 & First dorsal fin base length & 7.1 & 6.9 & 6.6 & 5.9 & 6.4 & 0.5 \\
\hline Interdorsal distance & 8 & 7.3 & 9.3 & 9.5 & 10.0 & 1.1 & First dorsal fin height & 6 & 6.0 & 6.0 & 5.1 & 6.7 & 0.5 \\
\hline Dorsal-caudal distance & 8 & 7.0 & 9.3 & 9.9 & 7.0 & 1.3 & First dorsal fin-inner margin & 2.7 & 2.8 & 3.0 & 4.1 & 3.3 & 0.5 \\
\hline Pectoral-pelvic distance & 16.1 & 18.9 & 17.9 & 19.4 & 15.2 & 1.8 & & 4.8 & 4.8 & 4.1 & 5.5 & 4.8 & 0.5 \\
\hline Anal-caudal distance & 6.6 & 5.8 & 8.5 & 7.9 & 7.3 & 1.1 & & & & & & & \\
\hline Eye length & 3.4 & 2.7 & 3.0 & 3.2 & 3.6 & 0.4 & Second dorsal fin length & 6.8 & 7.4 & 7.4 & 6.3 & 7.3 & 0.5 \\
\hline Eye height & 0.8 & 0.5 & 1.2 & 1.1 & 1.5 & 0.4 & ior & 6.4 & 6.6 & 5.8 & 5.5 & 6.7 & 0.5 \\
\hline Interorbital width & 8.9 & 9.1 & 8.2 & 8.5 & 9.7 & 0.6 & & & & & & & \\
\hline Nostril width & 2.9 & 3.5 & 4.4 & 2.6 & 3.6 & 0.7 & se & 5.1 & 4.8 & 3.0 & 4.3 & 4.2 & 0.8 \\
\hline Internarial space & 2.4 & 1.8 & 2.7 & 3.6 & 3.0 & 0.7 & & & & & & & \\
\hline Anterior nasal flap length & 1.5 & 1.3 & 3.8 & 2.7 & 3.6 & 1.2 & cond dor & 3.7 & 3.4 & 2.7 & 3.2 & 3.6 & 0.4 \\
\hline Spiracle length & 1.1 & 0.6 & 1.1 & 0.4 & 0.9 & 0.3 & & 2.5 & 2.7 & 2.2 & 2.8 & 2.7 & 0.2 \\
\hline Eye-spiracle distance & 1.2 & 1.2 & 1.4 & 1.2 & 1.5 & 0.2 & & & & & & & \\
\hline Mouth length & 4.9 & 4.6 & 4.4 & 6.3 & 7.3 & 1.2 & d dorsal fin-posterı & 3.3 & 3.4 & 2.5 & 2.4 & 3.3 & \\
\hline Mouth width & 14.5 & 15.1 & 14.6 & 15.8 & 16.6 & 0.9 & Anal fin length & 9.2 & 8.9 & 8.8 & 8.7 & 7.3 & 0.8 \\
\hline First gill slit height & 3.8 & 3.4 & 1.8 & 2.1 & 1.8 & 0.9 & Anal fin- & 7.9 & 7.4 & 5.8 & 6.7 & 7.0 & 0.8 \\
\hline Second gill slit height & 3.7 & 3.6 & 3.8 & 2.8 & 2.1 & 0.7 & length & & & & & & \\
\hline Third gill slit height & 3.2 & 3.2 & 3.6 & 2.4 & 2.4 & 0.5 & Anal fin ba & 6.7 & 5.8 & 6.3 & 6.3 & 5.8 & 0.4 \\
\hline Fourth gill slit height & 3.1 & 3.3 & 3.3 & 2.8 & 2.1 & 0.5 & Anal fin height & 3.8 & 3.8 & 2.5 & 2.8 & 3.3 & 0.6 \\
\hline Fifth gill slit height & 2 & 2.1 & 1.6 & 2.0 & 1.8 & 0.2 & & 2.8 & 2.9 & 2.6 & 2.4 & 2.6 & 0.2 \\
\hline Head height & 7.2 & 11.2 & 9.1 & 8.9 & 9.3 & 1.4 & & & & & & & \\
\hline Trunk height & 9.3 & 13.4 & 8.8 & 10.7 & 11.2 & 1.8 & fin- & 4.3 & 3.9 & 3.5 & 3.6 & 4.2 & 0.4 \\
\hline Caudal peduncle height & 3.2 & 2.7 & 3.6 & 4.3 & 3.9 & 0.6 & & & & & & & \\
\hline Head width & 20.4 & 21.9 & 19.0 & 19.4 & 20.9 & 1.2 & gin & 21.2 & 20.4 & 21.7 & 22.1 & 23.0 & 0 \\
\hline Trunk width & 14.4 & 20.0 & 20.3 & 20.8 & 21.8 & 2.9 & & & & & & & \\
\hline Caudal peduncle width & 2.4 & 2.1 & 2.5 & 4.3 & 3.9 & 1.0 & & 9.5 & 9.8 & 9.3 & 9.9 & 10.3 & 0.4 \\
\hline Pectoral fin length & 12.8 & 13.8 & 11.5 & 11.5 & 13.0 & 1.0 & & & & & & & \\
\hline $\begin{array}{l}\text { Pectoral fin-anterior margin } \\
\text { length }\end{array}$ & 14.5 & 14.7 & 12.9 & 13.0 & 15.5 & 1.1 & $\begin{array}{l}\text { Caudal fin-subterminal } \\
\text { margin length }\end{array}$ & 4.1 & 4.0 & 4.4 & 4.3 & 4.2 & 0.2 \\
\hline Pectoral fin base length & 8.9 & 8.4 & 8.2 & 8.3 & 9.4 & 0.5 & $\begin{array}{l}\text { Caudal fin-subterminal } \\
\text { margin width }\end{array}$ & 4.1 & 3.9 & 3.6 & 3.6 & 4.8 & 0 \\
\hline Pectoral fin height & 11.5 & 12.7 & 10.4 & 11.5 & 12.7 & 1.0 & Caudal fin-terminal margin & 5.4 & 5.6 & 4.7 & 3.6 & 6.4 & 1.1 \\
\hline $\begin{array}{l}\text { Pectoral fin-inner margin } \\
\text { length }\end{array}$ & 5.2 & 5.8 & 4.9 & 5.1 & 5.8 & 0.4 & & & & & & & \\
\hline & & & & & & & Caudal fin-terminal lobe & 6.3 & 6.5 & 5.2 & 5.9 & 6.1 & 0. \\
\hline
\end{tabular}




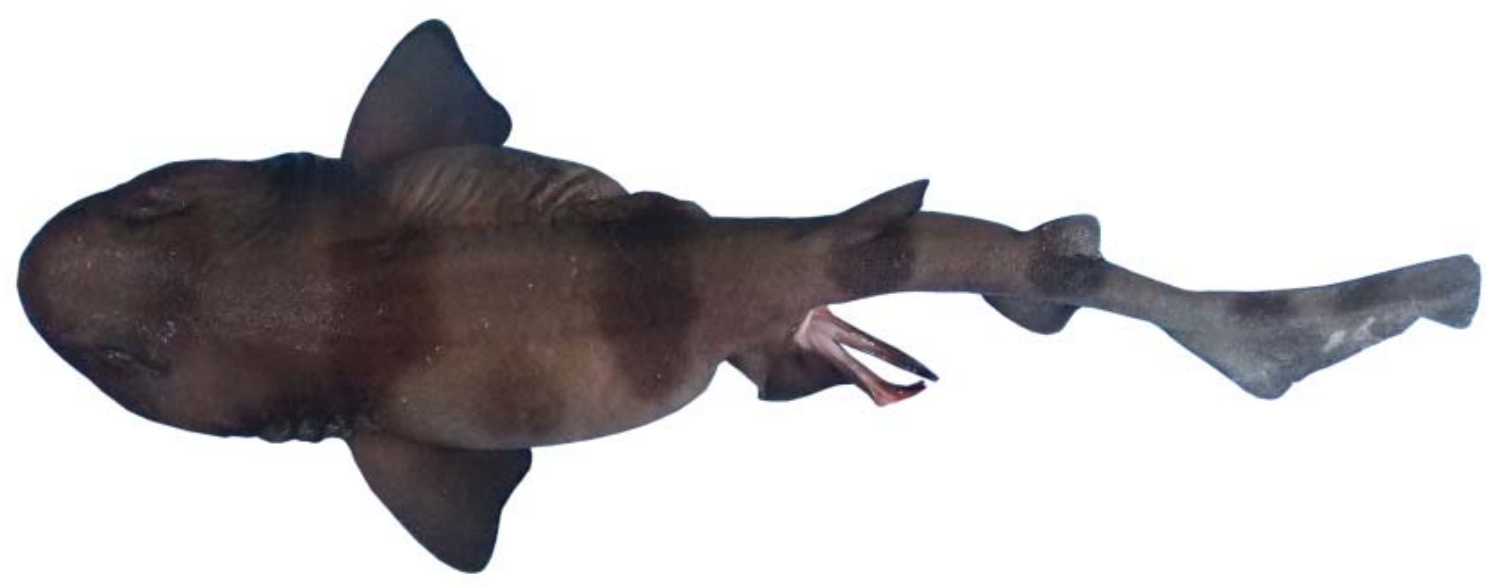

Fig. 2. Dorsal profile of Cephaloscyllium silasi from Andaman waters

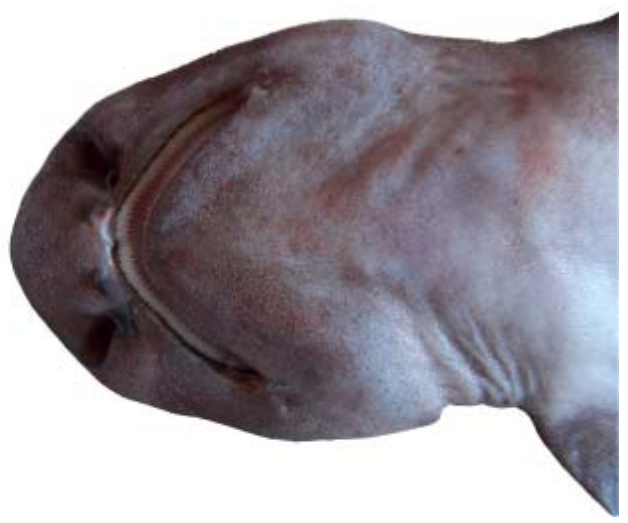

Fig. 3. Ventral view of the head of Cephaloscyllium silasi from Andaman waters

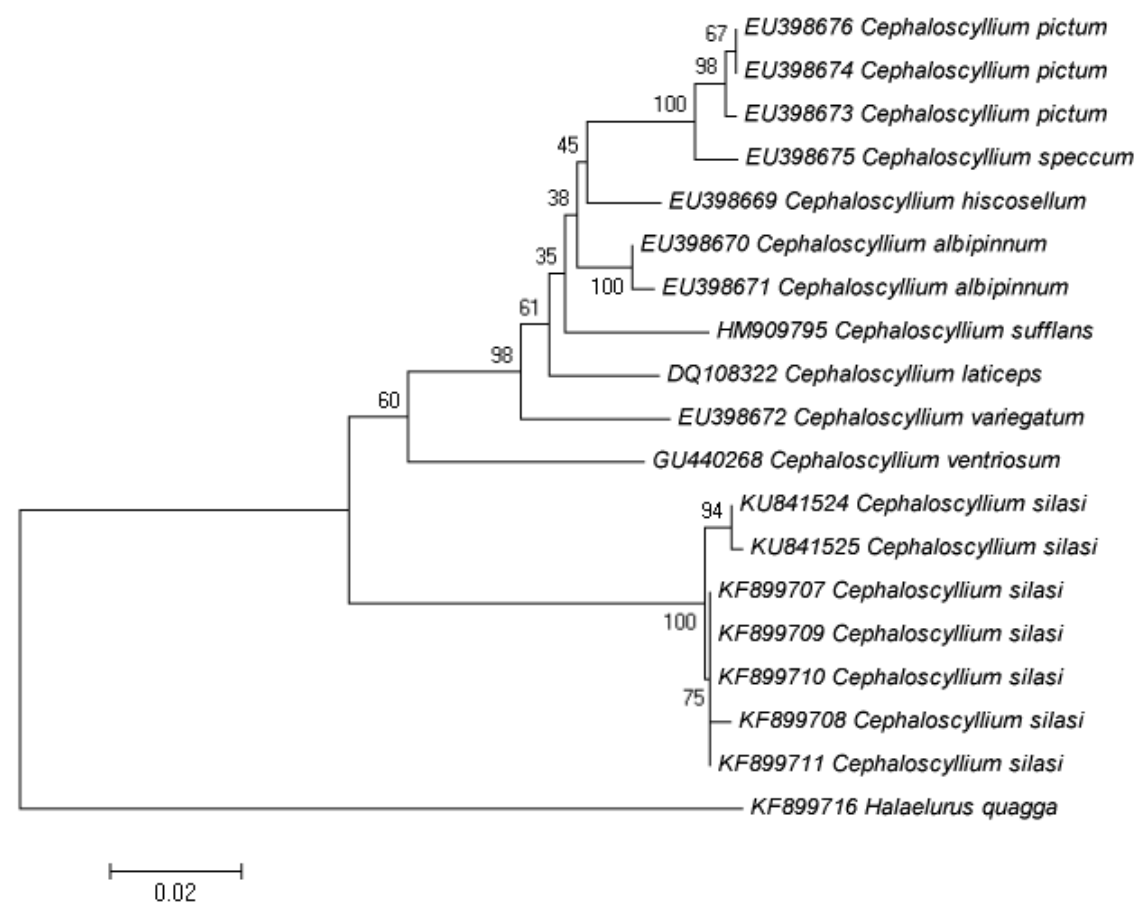

Fig. 4. Neighbour Joining (NJ) phylogenetic tree of Cephaloscyllium spp. inferred from DNA sequences of mitochondrial COI gene 


\section{REFERENCES}

Akhilesh K.V., Bineesh K.K., Ganga U., Pillai N.G.K. 2014a. Notes on the Indian swellshark, Cephaloscyllium silasi (Scyliorhinidae: Carcharhiniformes) from deep waters off the west coast of India. Marine Biodiversity Records 7: e25. DOI: $10.1017 / \mathrm{S} 1755267214000141$

Akhilesh K.V., Bineesh K.K., Gopalakrishnan A., Jena J.K., Basheer V.S., Pillai N.G.K. 2014b. Checklist of Chondrichthyans in Indian waters. Journal of the Marine Biolological Association of India 56 (1): 109120. DOI: $10.6024 /$ jmbai.2014.56.1.01750s-17

Bineesh K.K., Gopalakrishnan A., Akhilesh K.V., Sajeela K. A., Abdussamad E. M., Pillai N.G.K., Basheer V.S., Jena J.K., Ward R.D. 2016. DNA barcoding reveals species composition of sharks and rays in the Indian commercial fishery, Mitochondrial DNA Part A: Mapping, Sequencing, and Analysis. DOI: 10.3109/19401736.2015.1137900

Compagno L.J.V. 2001. Sharks of the world. An annotated and illustrated catalogue of shark species known to date. Bullhead, mackerel and carpet sharks (Heterodontiformes, Lamniformes and Orectolobiformes). FAO species catalogue for fishery purposes No. 1 Vol. 2. Rome.

Compagno L.J.V., Dando M., Fowler S. 2005. A field guide to sharks of the world. Harper Collins Publishing, London, UK.

Ebert D.A., Fowler S., Compagno L.J.V. 2013. Sharks of the world; A fully illustrated guide. Wild Nature Press, Plymouth, UK.

Hubert N., Meyer C.P., Bruggemann H.J., Guérin F., Komeno R.J.L., Espiau B. 2012. Cryptic diversity in Indo-Pacific coral-reef fishes revealed by DNAbarcoding provides new support to the centre-ofoverlap hypothesis. PLoS ONE 7 (3): e28987. DOI: 10.1371/journal.pone.0028987

Inoue S., Nakaya K. 2006. Cephaloscyllium parvum (Chondrichthyes: Carcharhiniformes: Scyliorhinidae), a new swellshark from the South China Sea. Species Diversity 11 (2): 77-92.
Kimura S., Satapoomin U., Matsuura K. (eds.) 2009. Fishes of Andaman Sea, West Coast of Southern Thailand. National Museum of Nature and Science, Tokyo, Japan.

Manilo L.G. 1993. New reports of fish on the shelf and upper slope of the western Indian Ocean. Journal of Ichthyology 33 (1): 128-136.

Miller S.A., Dykes D.D., Polesky H.F. 1988. A simple salting out procedure for extracting DNA from human nucleated cells. Nucleic Acids Research 16 (3): 1215.

Rajan P.T., Sreeraj C.R., Venkataraman K. 2012. [Chapter 8] Diversity and abundance of chondrichthian fishes in Andaman and Nicobar Islands. Pp. 117126. DOI: 10.1007/978-3-642-28335-2 8. In: Venkataraman K., Raghunathan C., Sivaperuman C. (eds.) Ecology of faunal communities on the Andaman and Nicobar Islands, Springer-Verlag, Berlin, Heidelberg. DOI: 10.1007/978-3-642-28335-2

Randall J.E. 1998. Zoogeography of shore fishes of the Indo-Pacific region. Zoological Studies 37 (4): 227 268.

Schaaf-Da Silva J.A., Ebert D.A. 2008. A revision of the western North Pacific swellsharks, genus Cephaloscyllium Gill, 1862 (Chondrichthyes: Carcharhiniformes: Scyliorhinidae), including descriptions of two new species. Zootaxa 2008 (1872): 1-8.

Talwar P.K. 1974. On a new bathypelagic shark, Scyliorhinus (Halaelurus) silasi (Fam. Scyliorhinidae) from the Arabian Sea. Journal of the Marine Biological Association of India 14 (2): 779-783.

Ward R.D., Zemlak T.S., Innes B.H., Last P.R., Hebert P.D.N. 2005. DNA barcoding Australia's fish species. Philosophical Transactions of the Royal Society of London, Biological Sciences 360: 1847-1857. DOI: $10.1098 /$ rstb.2005.1716

Weigmann S. 2016. Annotated checklist of the living sharks, batoids and chimaeras (Chondrichthyes) of the world, with a focus on biogeographical diversity. Journal of Fish Biology 88 (3): 837-1037. DOI: $10.1111 /$ jfb. 12874

Received: 11 March 2016 Accepted: 25 June 2016 Published electronically: 30 June 2016 